\title{
The Changing Uyghur Religious Soundscape
}

\author{
Rachel Harris, SOAS, University of London \\ Performing Islam (2014) Volume 3, Numbers 1 \& 2, pp. 93-114
}

Rachel Harris is Reader in the Music of China and Central Asia at SOAS, University of London. Her research interests include global musical flows, identity politics, gender, and ritual. She is the author of two books on musical life in China's Xinjiang Uyghur Autonomous Region: 'Singing the Village' (Oxford University Press, 2004), and 'The Making of a Musical Canon in Chinese Central Asia' (Ashgate, 2008). She is co-editor of three books: 'Situating the Uyghurs' (Ashgate 2007), 'Gender in Chinese Music' (University of Rochester Press 2013), and 'Pieces of the Musical World' (Routledge 2015). She currently leads an AHRC Research Network and the Leverhulme Research Project 'Sounding Islam in China'. She is actively engaged with outreach projects relating to Central Asian and Chinese music, including recordings, musical performance, and consultancy.

Key words: Islam, soundscape, Uyghur, Xinjiang, media

\begin{abstract}
Recent studies in the anthropology of Islam have called for a new understanding of the relationship between global forms of Islam and local priorities, new ideologies and everyday religious experience. This article addresses these concerns in the context of Uyghur society in the Xinjiang Uyghur Autonomous Region of China where communities are increasingly engaging with transnational currents of Islamic ideology, and increasingly under pressure from the state which conflates religiosity with anti-state activity and extremist terrorism. The article focuses on Islamic media, in particular at the ways in which rural Uyghur women experience and reproduce globalized forms of Islamic media. It aims to understand how the most marginalized sectors of society are engaging with these changing religious ideologies and practices. The theoretical frame draws on notions of the 'soundscape', which explore the ways in which sound, practices of listening, and perceptions of sound, may be central to making sense of the world around us.
\end{abstract}

\section{Snapshots in Sound from Xinjiang}

The massive development of recent decades in the Xinjiang Uyghur Autonomous Region of China has brought rapid advances in infrastructure, the wholesale extraction of natural resources, and largescale Han Chinese immigration into a region once dominated by Turkic Muslim peoples, the most 
numerous of which are the Uyghurs. This development has wrought huge changes not only in the landscape but also in the soundscape. The noise of heavy industry threatens at times to drown out human sound. Coal mines and oil refineries now dominate the desert landscape, and heavy lorries thunder up and down the new highways transporting minerals and building materials. The thud of pile drivers echoes around the high-rise residential developments that are shooting up in Xinjiang's provincial cities. In the Muslim cemetery in Ürümchi there is an audible hum from the electricity pylons and the mass of wires that pass overhead; relatives complain that the noise is disturbing the sleep of the dead. In the Uyghur villages, cement mixers grind as peasant farmers take advantage of government grants to rebuild their homes; the nights throb to the sound of water pumps, as the farmers take advantage of the cheaper rate electricity to pump water to their cotton fields.

State media continues to claim its space in the Uyghur soundscape: another striking development in 2012 was the return of the village loudspeaker, that supreme sonic marker of the Chinese Cultural Revolution, once again broadcasting music - mainly Uyghur pop songs - and news: production targets met and exceeded, and the latest regional and national political campaigns. In the Handominated public spaces of Xinjiang's provincial cities, centred on the beautifully manicured town squares (guangchang), the evening soundscape is transformed into a noisy carnival as urbanites come out to enjoy forms of leisure characterized by 'heat and noise' (renao): groups of middle-aged women enjoy American line dancing or Chinese yang'ge dancing to loud pop soundtracks which compete with tinny music from children's fairground rides, while elderly men stroll by holding radios from which emanate the sounds of Chinese opera.

Attention to sound has become more mainstream in anthropological studies over the past decade, intersecting with interests in the field of ethnomusicology (Erlmann 2004). Stephen Feld has coined the term 'acoustemology' to describe 'an exploration of sonic sensibilities, specifically of ways in which sound is central to making sense, to knowing, to experiential truth' (Feld 1996: 97). A related trend in anthropology and ethnomusicology builds on the notion of the 'soundscape', a term coined in the 1970 s by Canadian composer Murray Schafer. Schafer's projects can be linked to the environmental concerns and anxieties of urbanisation and industrialisation that were current at the time; anxieties that are certainly moot in contemporary Xinjiang. However more recent writing around the idea works more broadly to create new possibilities for thinking about the links between the social and physical environment, and for thinking about listening as a cultural practice (Samuels et al. 2010: 330).

What can attention to sound contribute to our understanding of recent developments and tensions in Xinjiang? How do social and ideological transformations entwine with the soundscape? The sonic snapshots sketched above give a fleeting impression of the lived experience of development for local people in Xinjiang. Its noise is inescapable, overwhelming; sometimes alienating and fearful, sometimes a tolerated or even welcomed marker of private achievements: a new home or a good cotton crop. These snapshots also point to the increasing segregation of social space in Xinjiang's cities. The heat and noise of the public squares mark not only the increasing numbers of Han Chinese migrants but also their increasing confidence to claim and dominate public space. Many Uyghurs parents of young children, groups of teenagers and young couples - regularly visit the public squares and enjoy the leisure opportunities and freedoms they afford, but others - the older generation in particular - experience these spaces almost as tourists in their own land, marvelling at the pace of change, the new technologies and the extraordinary, alien, heat and noise.

In this article I refer to the Uyghur soundscape, privileging the ethnic group as a site of investigation rather than the geographical region of Xinjiang. This focus might at first glance seem counterintuitive if we easily equate soundscape with landscape, but if we understand soundscape as a cultural production then in this ethnically divided region soundscapes are also ethnically marked. A whole range of sounds are differently perceived by different ethnic groups, indeed many sounds of 
key importance to one group may be barely audible to others. Ethnicity is, of course, not the only marker of identity and difference in this region, but it is salient, and it forms the basis for this investigation.

\section{The new Islamic soundscape of Erdaoqiao}

A growing body of work applies these approaches to Islamic societies across the Middle East, North Africa and Indonesia, and develops the notion of specifically Islamic soundscapes: ones which are created, experienced and interpreted in ways particular to the Muslim people who inhabit them (Hirschkind 2006; Eisenberg 2009; Rasmussen 2010). Likewise in Xinjiang it is possible to listen in on a specifically Uyghur Islamic soundscape: one inhabited and interpreted by Uyghur Muslims.

Between the years of 2009 and 2012, a remarkable transformation occurred in the soundscape of the Uyghur area of Ürümchi, the regional capital of Xinjiang. These changes were not obviously modern in the way of the Han Chinese-dominated soundscape of the public squares, but they clearly indexed an alternative form of modernity. The Uyghur part of the city is centred on the area of Erdaoqiao (Dong Kövrük), the city's main mosque and the new Big Bazaar: a recent tourism and shopping development where a fake minaret modelled on Bukhara is adorned with huge advertisements for Kentucky Fried Chicken. Under Qing imperial rule, this area lay south of the city gates and was little more than a shantytown for Uyghur traders. In 2009, this was the area through which Uyghur students marched to protest against killings of Uyghur workers in China's southern factories, and where some of the worst interethnic violence ensued after armed police broke up the demonstration (Millward 2009). In the months that followed the violence, the existing segregation of the city grew much sharper, as Han residents moved out and Uyghurs from the Han-dominated northern part of the city moved in. At the same time, a striking Islamization of the space occurred.

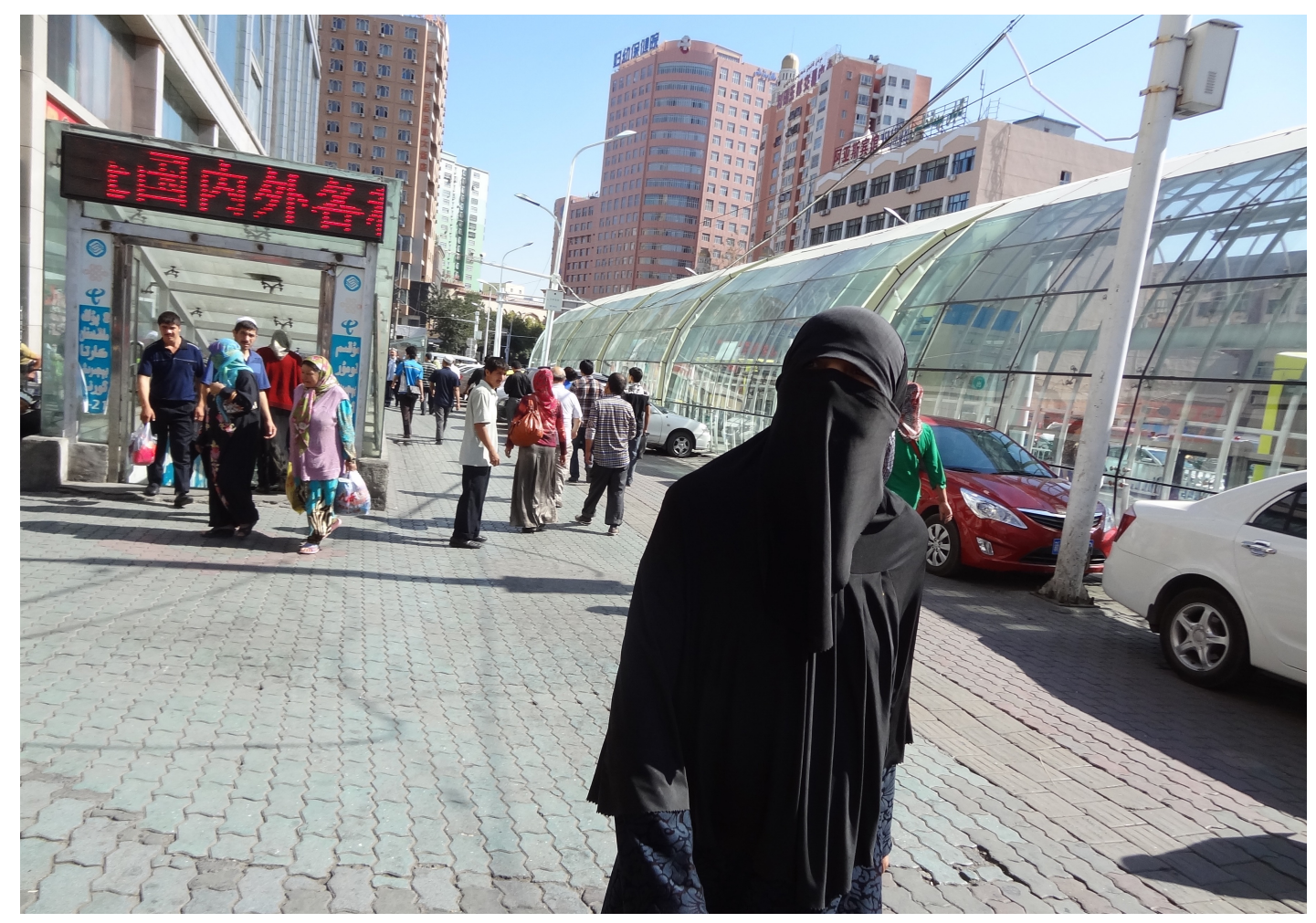

Figure 1: Woman wearing the niqab in Ürümchi. Courtesy of Aziz Isa. 
When I returned to the region after a break of three years in summer 2012, the changes were visibly, and contentiously, marked by women's choice of dress. Numerous young women could be seen on the street fully covered in what Uyghurs call the 'Arab style' of dress, some in full length black robes including the niqab facial veil, others following alternative fashions, their heads swathed in fake Burberry checked scarves. Such clothing choices were not unknown a decade ago, but before 2009 women who chose to fully veil in this manner formed a tiny minority, and stood out against the traditional light headscarf tied over the hair behind the neck, and the many, usually educated women who went about uncovered. In another new development, stallholders on the street were openly selling privately produced Uyghur language books and pamphlets to teach the basics of daily prayers and Qur'anic recitation (qira'ät), alongside an array of Islamic talismans and charms; prayer beads and blue glass discs to avert the evil eye imported from Turkey. Cigarettes had disappeared from the shops, and most restaurants had stopped selling alcohol, where before Uyghur men had sat openly smoking and drinking strong Chinese liquor. 'They take up space for too long, and fight, and it is against our religion', said a restaurant owner. There were rumours of murders: a drunken man had been set upon as he wandered home at night, and his mutilated body dumped in front of the main mosque.

The Islamic soundscape of Erdaoqiao in 2012 was still far more muted than the glorious cacophonies of Mombasa or Jakata, but compared to my previous visits over the past decade, it was a veritable riot of religious sounds. Where before Uyghur pop songs and traditional dutar melodies had dominated, now imported DVDs of nasheed religious songs, many sung in Arabic or even in English, could be heard from the restaurants. On Friday at noon the sound of the sermon from the mosque never previously audible - was carried by loudspeakers out into the surrounding streets. The garden of the mosque was crowded with men praying. On the pavement outside boys sold prayer mats and surreptitiously showed to interested customers an array of illegal religious VCDs adorned with improving images such as a glass of beer overlying the flames of Hell, or two kneeling skeletons, their bony arms upraised in ecstatic prayer.

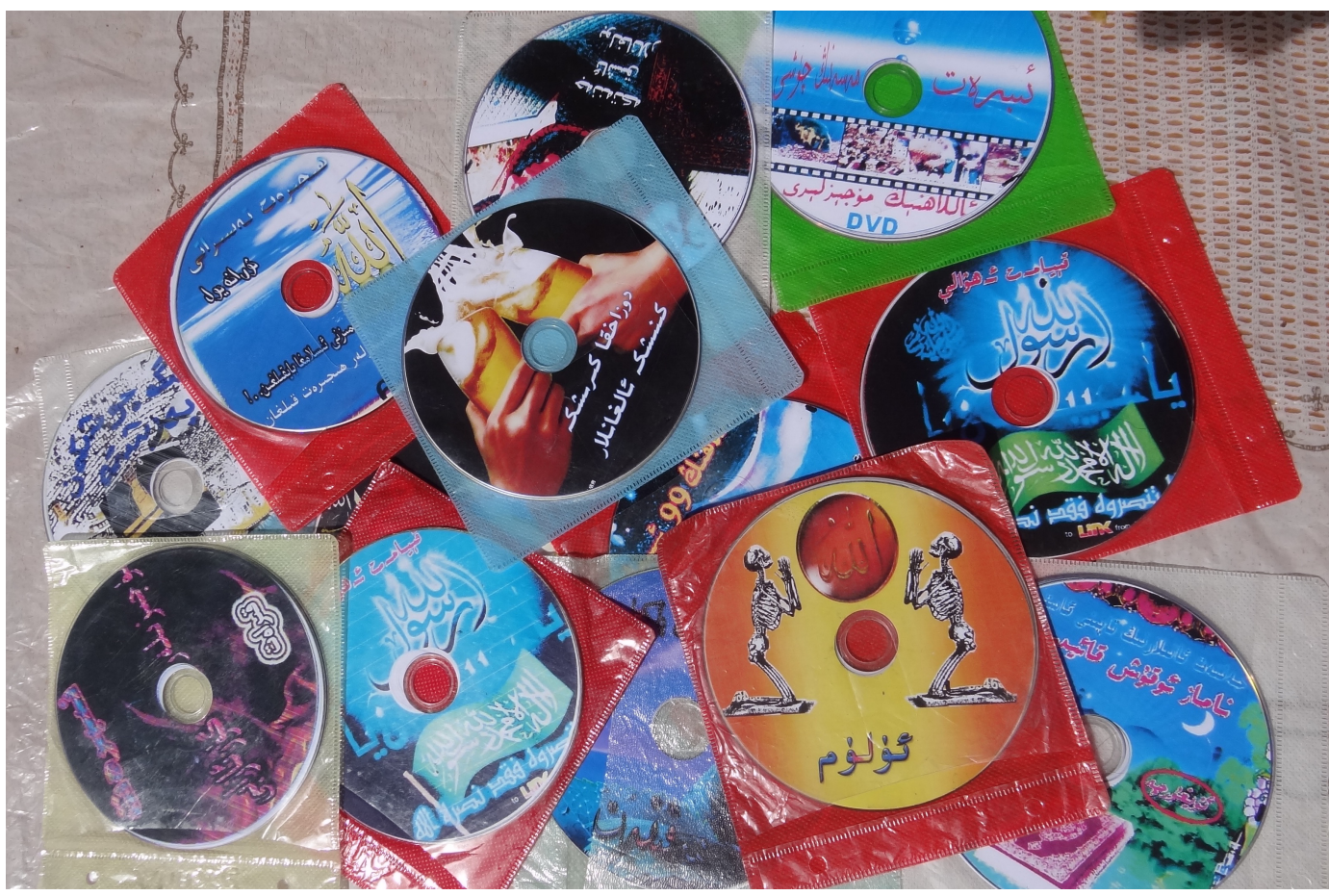

Figure 2: Religious VCDs. Courtesy of Aziz Isa. 


\section{Changing patterns of Islamic faith: a soundscapes approach}

Recent studies of Muslim societies have paid close attention to forms of negotiation, contestation, and control over sacred authority and correct practice (Soares \& Osella 2009). Many authors have focused on the expansion of the public sphere and various new publics, as well as the effects of media technologies on contemporary religious discourse and practices (Hirschkind 2006; Ho 2010). Magnus Marsden proposes 'a new and different understanding of the relationship between Islam, everyday religious experience and interpersonal relationships in Muslim societies' which takes into consideration the complexity of interactions between local systems of aesthetics and global forms of religious transformation (Marsden 2005: 22-23). Saba Mahmood calls for scholars to interrogate the practical and conceptual conditions under which different forms of desire emerge, arguing that:

We need to pay attention to local explanations - the terms that people use to organize their lives are not simply a gloss for universally shared assumptions about the world and one's place in it, but are actually constructive of different forms of personhood, knowledge, and experience. (Mahmood 2005: 16)

This article applies these questions in the context of Uyghur society in the Xinjiang Uyghur Autonomous Region of China, using a focus on sound and the soundscape as a means to explore them. Although Islamic religious practice in Xinjiang remains firmly under the control of the Chinese Communist Party (CCP), many of the contemporary realities faced by Muslims in this region are similar, indeed directly related to those confronting Muslims in the former Soviet Union (Hann 2006), in particular increasing exposure to transnational currents of Islamic ideology, and increased pressure from the state which conflates religiosity with anti-state activity and extremist terrorism. This article pursues a set of related questions: How does the Uyghur religious soundscape reflect the rise of new forms of Islam? What do these new religious modalities sound like, and more importantly, how do people listen to them? Thus I am interested in not only how these sounds reflect new realities, but also how they help to construct new ways of being Muslim and being Uyghur in Xinjiang.

The Xinjiang media has frequently highlighted state concerns about the influence of Islamic media imported from outside in Xinjiang. Such media items are typically portrayed as dangerous polluting influences, ones that purvey religious extremism, damage inter-ethnic harmony, and promote terrorism. In this article I follow state concerns by taking a closer look at the circulation of Islamic media in Xinjiang, in order to understand the ways that their sounds are absorbed, understood, and reproduced within Uyghur society. I am particularly interested in two types of sounds that are prevalent in these forms of media: horror film sound effects and Qur'anic recitation. The circulation of these sounds provides insights into the global-local dynamics of Islamic ideologies and practices, their changing meanings as they enter new contexts, their affective impact, and power to persuade and transform.

New forms of Islam arise and develop among different sectors of Uyghur society in different ways. In this article I focus primarily on the religious experience and practice of rural Uyghur women farmers and small traders - in the Aqsu region of southern Xinjiang, where I have conducted fieldwork over several years. ${ }^{1}$ The religious practice of these women is of particular interest in the project of listening beyond text, following the suggestion by David Panagia that an exclusive focus on discourse creates a de facto partition between those who can and cannot speak, between appropriate and inappropriate sounds. Panagia propose an account of the utterance attentive to those qualities that extend beyond its semantic texture and grammatical boundaries (Panagia 2009: 47-8). Rural Uyghur women represent one of the most marginalized sectors of Uyghur, distanced from power in terms of religious and political institutions, least able to speak within the parameters 
of mainstream discourse. The ways in which they do speak are easily dismissed by educated, rationalist Uyghurs as ignorant, superstitious, and backward. They are most likely to be portrayed in the Xinjiang media and in Uyghur popular culture as idealized repositories of tradition, and passive nostalgic symbols. In fact, many of these women are highly networked individuals who exercise considerable social and political agency. Kandiyoti and Azimova suggest that Central Asian women's ritual activities are strongly responsive to social change since participants experience the economic, social, and religious components of ritual and associational life as a seamless totality (Kandiyoti \& Azimova 2004: 336). As I will argue, their religious utterances are in no sense remnants of the past but are rather in active dialogue with global flows of Islamic ideologies, and current social and ideological change within Xinjiang.

\section{A brief history of Islam in the Xinjiang Uyghur Autonomous Region of China}

During the first few years of Chinese Communist Party (CCP) rule in Xinjiang, the Party adopted a relatively cautious and tolerant approach towards Islam. Shariah courts and the office of qazi (religious judge) were abolished in 1950, but the rights of Muslims to mosque land were protected. The Islamic Association of China was formed in 1953 to manage the training and oversee officially sanctioned religious clerics. During the Cultural Revolution period, Islam was regarded as part of the 'four olds': customs, cultures, habits, and ideas fostered by the exploiting classes to poison the minds of the people. The period saw humiliation of religious practitioners and burning of Qur'ans, but continued covert practice and transmission, and increased domestication of religion, as in Soviet Central Asia under Soviet rule, with the household becoming the primary locus for religious activities (Waite forthcoming).

The Islamic Association of China was reconvened in 1980 after a break of 17 years. Today, the main officially sanctioned college for training religious professionals in Xinjiang is the Islamic Institute in Ürümchi. Its curriculum, which includes study of the Qur'an, Hadith, Law, Arab language, and Communist Party ideology, is governed by the Islamic Association of China, and only its graduates can serve as official imam in the region's mosques (Fuller \& Lipman 2004). The subjugation of official clerics to the state has implications for the religious legitimacy of these leaders. There have been several high profile attempted and successful murders of prominent imam in southern Xinjiang since the mid-1990s. Yet most imam command the respect of the community, and successfully negotiate the twin roles of providing religious guidance and complying with government directives. Officially endorsed religious literature is available in state bookshops, and the Islamic Association organizes the pilgrimage to Mecca (hajj) every year for a select group of well-connected pilgrims.

However, in many ways state policies are directly hostile to religious practice and transmission in this region. State employees and students must not be seen to follow any religion, and numerous ordinary aspects of Muslim observance, such as abstinence from pork, daily prayers and fasting, veiling or growing beards, are periodically criticized as antisocial or illegal. Since the onset of the first 'strike hard' (yanda) campaign in 1996, a wide range of religious practices which lie outside the sphere of the officially controlled mosques - including shrine pilgrimage, religious instruction of children, and home-based healing rituals - have been designated 'illegal religious activities' (feifa zongjiao huodong). These are frequently linked to 'separatism' (fenlie zhuyi, i.e. ethnic nationalist projects to 'split the motherland') and with 'terrorism' (kongbu zhuyi) in official discourse, and practitioners may be subject to fines, imprisonment, and in extreme cases the death penalty (Becquelin 2004; Harris 2013; Uyghur Human Rights Project 2013).

In spite of, or perhaps in part because of these fierce restrictions, Islamic reformist ideas have been disseminated within Uyghur society since at least the late 1980s, and since 2009 appear to have achieved a tipping point. These new ideologies are transmitted not only via the Internet but also by 
various actors within transnational Islamic fields, including Uyghur intellectuals, merchants, wealthy Uyghurs returning from the hajj, and young men receiving a religious education abroad. ${ }^{2}$ Paula Schrode (2008) argues that these trends represent a new fusion of social prestige, economic power, staged piety and Islamic knowledge. Wealthy local merchants acquire social prestige by accomplishing the hajj and sponsoring the new mosques that are now a prominent feature of the landscape. The hajj also represents an opportunity to acquire new, first-hand knowledge of Islam, and to compare local Islam with the kinds promoted in Saudi Arabia and elsewhere. In this context, Uyghur Muslims who demand the 'purification' of traditional Uyghur Islam from corruption and superstition (khurapatliq) are viewed as religiously cosmopolitan and knowledgeable, and they gain social prestige from their reformist stance.

While Schrode views the rise of these new ways of being Muslim primarily as a consequence of mobility and greater access to global Islamic debates, Joanne Smith-Finley has argued that the rise of new forms of Islam amongst the Uyghur should be read primarily as a strategy of resistance to the state, in particular a strategy for buttressing Uyghur ethnic identity in response to increasingly assimilationist policies. Smith-Finley contends that the Islamic renewal is driven by the failure of state development policies to provide equitable opportunities for Uyghurs, and that economic and cultural marginalization are the principal drivers that have led many Uyghurs to seek out the forms of personal transformation that are afforded by religious piety (Smith Finley 2013: 287-9). While reformist Uyghur Muslims often refer to themselves as sünnätchi (followers of the Sunnah ${ }^{3}$ ) the state's fears of religious extremism are explicitly directed at 'Wahhabism'. ${ }^{4}$ Official imams regularly preach against Wahhabis in the region's mosques, and all sorts of violent incidents in the region are routinely attributed to Wahhabis in the Chinese media. Dru Gladney has argued that the term 'Wahhabi' in Xinjiang is 'a euphemism in the region for strict Muslims not an organized Islamic school' (Gladney 2004: 257).

Several encounters during my own fieldwork in 2012 serve to illustrate the complexities of these new religious identities. We attended a $n a ̈ z i r^{5}$ (death ritual) held by a pious family from southern Xinjiang who had set up a successful IT business in Ürümchi. An elderly official imam from their hometown also attended. During the meal, the brothers of the family criticized the imam aggressively: 'Why do you preach about unity of the nationalities in your mosque? Why do you allow the Chinese flag to hang on your mosque? Why don't you preach about how to be a good Muslim? Tell them: don't drink, don't smoke, work hard. We will all die. You should preach true Islam before you die'. They also clashed over the details of ritual procedure. When the imam tried to pray for the soul of their father who died several years previously, they stopped him short. 'Let our father rest in peace; why do you pray for him now when he has been dead for years?' The imam was very upset and afterwards privately accused them of being Wahhabis, yet the practice of näzir is itself heavily criticized by reformists in Xinjiang.

A government worker complained to us (unofficially) that religion had overtaken nationality as a marker of identity: 'The other day a family came to ask me for help, and they said, please help us because we are all Muslims. I asked, why don't you say, because we are all Uyghurs?' There is no such thing as Wahhabism, he told us. Uyghur girls are adopting the 'Arab style' of full-face veiling not because of any serious religious belief but because it annoys the Chinese. But his wife was fasting during Ramadan; possible for her even though she was a teacher in a state school because in that year it fell in the school holidays. His son was drinking heavily a few years ago, but had lately started to perform his daily prayers (bäsh namaz). A Uyghur colleague based at a Xinjiang university commented that there were many new views of Islam current in Ürümchi, which in her view were largely spread by the internet: 'If you sit five people down and ask them about Islam they will argue about five different interpretations'. 


\section{Islamic media in Xinjiang}

Questions concerning the use of the Internet and other forms of digital media as vehicles for religious and political mobilization have been widely addressed in the literature on Islam in the Middle East and elsewhere (Gladney 2004; Hirschkind 2012; Ho 2010). Much of this literature has focused on the political geography of Islamic forms of knowledge and experience as it is refashioned in the context of new technologies of mediation, and how it is weakening the norms and institutions of traditional religious authority. Dale Eickelman and James Piscatori (2004) have argued that with the spread of new media technologies there has been an increased fragmentation of authority in Muslim societies, a greater diversity of people speaking about what Islam is, and the 'traditional' interpreters of Islam have lost their monopoly. As we have seen, the Chinese state, which wields considerable control over the 'traditional interpreters' of Islam in China, is particularly concerned to control the spread of new religious ideologies carried by digital media, yet the periodic campaigns and crackdowns appear to have done little to stem the flow. We know from the spate of attacks on official imam, and the debates such as the one described above over the practice of näzir, that the authority of Xinjiang's official imams is today being challenged in multiple contexts, sometimes in ways that are discursive and sometimes in ways that involve physical violence. However, there is little available information about the kinds of Islamic media that are currently circulating within Xinjiang. What kinds of sounds and ideologies are carried by these 'illegal' religious media, and how are Uyghur Muslims absorbing and reinterpreting them?

Beginning in the 1980s, China opened up its borders after several decades of relative isolation. In Xinjiang, a lively Uyghur cassette industry swiftly developed, with Uyghur pop and traditional productions released by Chinese recording companies on sale alongside bootlegs of western pop, rock and light music, and Hindi film songs (Harris 2002). Religious media also filtered into the region, in the form of cassettes brought back from the hajj, and traded across the border from Pakistan and neighbouring Central Asian states. By the mid-1990s, the cassettes had largely been replaced by VCDs - a form of cheap digital video technology that is still widespread in China today. Under the periodic 'strike hard' or anti-religious extremism campaigns that began in the mid-1990s, the sale of Qur'anic recitation recordings and other religious media were prohibited, but the bans were uneven, and the black market has continued to flourish. As access to the Internet became more widespread in Xinjiang during the early years of the $21^{\text {st }}$ century, largely through the Internet cafes based in towns and cities across the region, new forms of access to global Islamic forms became possible, although heavily filtered by state control systems. In more recent years the explosion in smart phones and various forms of social media has enabled much more widespread peer-to-peer sharing of Islamic media. Many of the Islamic media items that circulate within Uyghur society can be found in multiple formats, and they flow freely between all these different media platforms.

During fieldwork in southern Xinjiang in 2012, I surveyed a selection of explicitly Islamic VCDs that were offered for sale on the black market and were enthusiastically consumed by rural women. They kept them hidden out of sight for fear of police raids on their homes, and told me that possession would earn them a short prison sentence. The media that they contained was diverse. Some appeared to be the products of backroom commerce by opportunistic small businessmen who had downloaded a seemingly random selection of Islamic music videos freely available on Chinese websites, and compiled and produced them as VCDs to sell to pious villagers in search of knowledge about their faith. Such VCDs could command a premium price because of the lure of the illicit; a phenomenon I have previously noted in relation to Uyghur nationalist music productions (Harris 2002: 279-80). They included large numbers of Arabic, Turkish and Malaysian soft pop style nasheed or illahi religious songs, predominantly with synthesized instrumental accompaniment and endless shots of waterfalls and flowers, all evidently downloaded from the mainstream Chinese equivalents of YouTube: Youku, Tudou or 56.com. International star singers featured strongly, such as the Turkish cosmopolitan modernist Sami Yusuf; several Malaysian Brothers groups (the Islamic 
equivalent of the UK Boy Bands), and the long-standing Uzbek pop diva Yultuz Osmanova in her religious phase with a remarkable New Romantic take on pious performance. There were also Arab language children's cartoons dubbed into Uyghur featuring plasticine camels explaining the meanings of the Festival of Sacrifice (Eid, or Qurban in Uyghur); an extremely poor quality copy of the 1977 Hollywood film of the life of Mohammed, 'The Message' directed by Moustapha Akkad, and a Xinjiang government information video for pilgrims about to embark on the hajj: hardly the stuff of extremism.

Other productions were equally diverse in origin, but seemed to be more consistent exercises in a form of religious ideology which drew on eschatological themes of suffering, death, judgement and fear of God in order in to promote the virtues of a pious lifestyle. One VCD titled 'Olum' (Death), whose cover depicted two kneeling skeletons, included a rather well-produced video apparently originating from Jordan which featured the death of a sinful young man at the hands of the angel Azra'il, portrayed by an actor in black robes holding scythe and chains. Like many other videos, it drew on classic tropes of horror film: the camera in the role of the approaching menace; the tight close-up on the terrified victim's face. Once the young sinner is despatched, the viewer watches with morbid fascination through the eyes of his ghost the ritual preparation and burial of his body, the grief of his relatives, and his final descent into the flames of hell. This sat alongside a video produced by the controversial Turkish author and creationist Harun Yahya which juxtaposed shots of the solar system with speeded up simulations of the human aging process. Other videos were notable for the way they evidenced processes of transnational remediation, remixing and overdubbing. Several of these included footage - apparently of Saudi origin - of hospital deathbeds and gruesome corpses overlaid by Qur'anic recitation and earnest sermons delivered in both the Uzbek and Uyghur languages. In his study of cassette sermons in Cairo, Hirschkind also comments on the use of audio and visual tropes drawn directly from the language of horror films, asking if we should feel surprise at this juxtaposition of the affective language of Hollywood and that of the holy Qur'an. He argues that one of the primary tasks of the sermon is to dwell on death, rooting it in the sensory experience of the pious listener, for fear of the fires of hell is a religious virtue. But cassette sermons are not only religious but also commercial entities, rooted in popular culture, and they employ the seductive and marketable images of horror film, because death sells (Hirschkind 2006: 312-316).

This random collection of religious media popular with Uyghur village women in 2012 seems to exemplify the processes of decontextualization and abstraction often remarked upon in discussions of digitally mediated productions, juxtaposing as it does a wide range of different ideological and affective relationships with Islam. It also suggests that, while some productions may seek to promote particular forms of Islam, Uyghurs who consume them are not using religious media in a dogmatic way to pursue specific ideologies. It would seem more appropriate to argue that what they seek are particular affective religious experiences, and the affective language of horror, used to promote pious virtues, is prominent. In order to further explore how these media items work within Uyghur society, I turn to one case study: the notorious video of the snake-monkey-woman.

\section{The Snake-Monkey-Woman}

In summer 2012 a video was circulating amongst Uyghurs in China's Xinjiang Uyghur Autonomous Region. Villagers flocked to Internet cafes to watch it online and they shared it on their smart phones. The video depicted what appeared to be the taxidermized remains of a snake, attached to the upper body and head of a monkey, wearing a wig of long, blonde hair. This object of horror was displayed on a table inside a home. The camera circled it while hands touched it (no faces were visible) and stroked its hair. The affective impact of the video was underlined by a spooky soundtrack of screams and pulsing synthesized beats. With its digitally manipulated, looped animal cries, this soundtrack employed familiar techniques of sound in horror films: using extremely high frequencies to connote 
an unknown threat, distorting familiar sounds to create a sense of unease. The extremely poor quality of the production only added to its aura of authenticity and power to terrify (what readers might know as the Blair Witch effect). It was particularly effective when viewed on smart phone. Girls and women in the village where we were staying were frightened. We first became aware of it when the nine year-old daughter of our host family began screaming hysterically one night, refusing to go to the toilet (which lay at the end of the garden) in case the 'snake woman' fell on her from the tree branches. Her mother asked me if such monsters really exist. The meaning of the video was variously interpreted by people we knew in the locality, but the dominant story emerged thus:

These were the remains of Maynur Hajim, a rich businesswoman from Ürümchi who was known to be fond of parties and dancing. (A somewhat insalubrious video of one of her parties had circulated online a year earlier and provoked copious disapproval). Her husband sent her on the hajj three times but she wouldn't give up her bad habits. One night she came home late. Her husband asked, 'What have you been doing?' She said, 'I have been dancing like a snake and jumping like a monkey'. The next morning he woke up to find his wife had been transformed into a snake-monkey-woman. He had a heart attack and died. They took the thing to the main mosque in Ürümchi, and it stayed there for several days until the government came and killed it by lethal injection.

My own response to this video and its surrounding stories was to assume that its appearance in rural Uyghur society represented an unpleasant attempt by some religious reformists to inculcate ethical behaviour in viewers through fear, and especially to discipline women by threatening the dangers of 'un-Islamic' bodily practices such as dancing. However, the layers of meaning which quickly accrued around it were quite different. Even before the video made a stir in our village, Uyghur netizens in Ürümchi were already posting online articles denouncing the snake woman as a 'fake miracle'. Some net-savvy individuals soon discovered that the video had originated in Malaysia in 2010 where a 'snake with a human head' had been displayed for money as a form of freak show, not in any way linked to religious ideologies. ${ }^{6}$ It had subsequently circulated Chinese online forums, and even been the subject of a TV documentary. Posts on Uyghur websites condemned the 'evil heart' of the person who had manipulated this video, added the 'horror' soundtrack, and reposted it on Uyghur sites with intent to 'shame Islam'. They also lamented the naivety of the Uyghurs who believed it:

We know that Allah performed many miracles (möjuz), but the ones that we find online today - the gigantic man, the girl who changed into a monkey, the pig woman - are they actually created by Allah? ... Some people even sell these videos on the black market. These videos have such a good market that the fraudsters can't keep up with demand, but such money is haram (ritually impure). Our [Uyghurs'] understanding of new technology is very low, so we are easily cheated. ${ }^{7}$

By mid-August the regional government was sufficiently alarmed to issue a news item, which was aired on local TV stations, saying that the story of the snake-monkey woman was fake, and was produced by the dissident exile organisation, the World Uyghur Congress in order to incite religious extremism and separatism. ${ }^{8}$ Uyghur netizens, on the other hand, hinted darkly that the video was actually produced by Chinese government agents who wanted to promote superstition amongst the Uyghurs in order to better control them.

These layers of interpretation that built up around the video provide only partial glimpses into its meanings. They serve primarily to reiterate existing stereotypes and entrenched attitudes. We need to listen to this item beyond the level of textual debate. The video itself is an utterance - recalling Panagia's use of the term - entirely free from semantic meaning. Its power lies in its immediate affective impact, produced through the combination of the sound language of horror films and the possibility that the monstrous - however fake-looking - might actually be real. As with any horror film, it held a strong fascination for many people we knew, and there was seductive pleasure in viewing it. A part of the video's power lay also in its openness to semantic interpretation. This was a 
juxtaposition of a Hollywoodesque soundtrack and video images of a Malaysian freakshow: two disparate items, free floating on the world-wide web, neither with any obvious relationship to Islam. Only through the rumours which accrued around the video did any religious meaning become attached to it. We also need to listen attentively to this noisy, messy, orally transmitted world of rumours.

State media have frequently conflated media events like this one with what they term online jihadist propaganda. In autumn 2013, for example, a news report on a new crackdown on religious media stated that:

Xinjiang police were investigating 256 people for spreading 'destabilising rumours' online, the Xinjiang Daily newspaper said. Of those, 139 spread rumours about jihad, or Muslim holy war, or other religious ideas. More than 100 had been detained. ${ }^{9}$

A brilliant mixture of the highly precise figures and the extremely vague delineation of what they refer to, this report suggests that what state media refers to as extremist terrorism, or jihad, often subsumes a far wider set of religious dispositions that the state regards as potentially threatening to stability. Thus, the snake-monkey-woman, like many other items of religious media, is subsumed under the rubric of jihadi propaganda. Another incident that occurred in Ürümchi a few years earlier, in 2009 , in the aftermath of the inter-ethnic violence illustrates all too vividly why rumours might be so alarming to the Xinjiang authorities. In September 2009, a crowd of Han Chinese marched to demand government action against Uyghurs after widespread rumours that Uyghurs were stabbing Hans with hypodermic needles infected with H.I.V. ${ }^{10}$ In his study of rioting crowds and interethnic violence in India, Stanley Tambiah describes rumours as eminently oral utterances; they circulate at high velocity by word of mouth, aided today by the Internet and smartphones, and they are the currency of mass movements. Rumours generally appear anonymous in origin, and by their nature they cannot be traced to definite culpable sources. Crowds are highly suggestible to rumours, which can rouse them to a collective state of intensified passions in which they may commit acts normally unthinkable to them as individuals (Tambiah 1996: 281).

Rumours, impelled by affective force, have considerable power to transform not only temporary states of mind but also more long-lasting ways of being. The snake-monkey-woman is threatening to the state on two levels: she defies reason and rational debate, and she viscerally promotes the simplest and most fundamental religious disposition, that of being 'God-fearing' ('men Khodadin qoqaymen'), thus diluting fear of the state's own temporal power. Several of the village women made this opposition between state and religious power explicit, such as in this case where a woman explains why she has not given up the currently illegal practice of providing religious instruction for children:

I was leading prayers one night and the police caught us. I was with one girl from Ürümchi, and two from Aqsu. They put me in jail for 15 days. After that Allah gave me even more strength and faith and I became even stronger. We shouldn't be afraid of them because Allah said on the Day of Judgement [qiyamät küni] even a mother will forget her baby.

\section{Style and ideology in Qur'anic recitation}

By far the most dominant sounded practice in the religious media circulating in Xinjiang in 2012 was the recited Qur'an: a sounded practice seemingly far removed from horror sound tracks but as we have seen often juxtaposed with them in the Islamic media circulating this region. Recordings of Qur'anic recitation came from many different sources, in many different styles, from short teaching videos produced by the Islamic Institute in Ürümchi, to imported VCDs from Pakistan and locally produced discs of Internet downloads; lengthy high quality recordings in the ornate 'classical' 
Egyptian style, and the simpler but emotive Saudi style, thick with reverb. Sometimes the recitation overlaid gruesome images of death and decay, but more often it was accompanied by images of skies or flowers, or the faithful praying in huge North African mosques.

For Muslims, the Qur'an is Divine Revelation, the fixed Speech of God as revealed in the Arabic language to the Prophet Muhammad. The Qur'an as text is inseparable from its recitation as solo vocal performance; Muslims rarely read the Qur'an without reciting it. For non-Arabic speaking Muslims, arguably, the experience of the sound of the recited Qur'an takes even greater precedence over the lexical meanings which may be barely understood. Hirschkind suggests that ways of sounding and hearing the Qur'an are central to the acquisition of a pious disposition even for those who find the language unintelligible on a semantic level. Numerous verses in the Qur'an describe the effects of godly speech on the rightly disposed listener. Surah Al-Anfal (Q8: 2) for example, states: 'Believers are only they whose hearts tremble whenever God is mentioned, and whose faith is strengthened whenever his messages are conveyed unto them' (Hirschkind 2006: 75). In her seminal study of Qur'anic recitation in Egypt, Kristina Nelson argues that the role of the reciter is not only to transmit the meanings of the text but also to stir the hearts of listeners with those meanings (Nelson 2001: 100).

Some aspects of Qur'anic recitation are governed by a set of rules called tajwid, but other aspects mainly the more melodic and expressive aspects of recitation - are not fixed by tajwid. Thus, experienced listeners can immediately identify regional styles of recitation, and even the individual style of a well-known reciter, whose style may be appreciated for its expressive power and ability to stir the heart: at once an aesthetic and religious experience. Through the course of the $20^{\text {th }}$ century, particular styles of Qur'anic recitation have achieved global hegemony through systems of technology and political patronage, and they have become linked to particular Islamic ideologies.

In the 1960s and 1970s, developments in recording technology permitted the global spread of what is now regarded as the classical Egyptian style, as Eygpt's state-owned recording company SonoCairo produced a series of star reciters, among them Abdul Basit 'Abd us-Samad and Khalil al Hussari, for world-wide export (Frishkopf 2009: 79-83). Renowned for their artistry, their recitation style featured dramatic melodic ornamentation and ecstatic techniques of repetition and modulation. In recordings of their live performances, sighs and shouts of appreciation from the audience are often audible. In the 1980s, a new style of recitation began to compete with this established style via a new media form. Saudi New Islam was widely promoted through cassette recordings of sermons and recitation. In contrast to the ornate Egyptian style, the Saudi style is typically rapid and simple. The heavy reverb used in its recordings indexes the acoustics of its most common live venues, the huge mosques at Mecca and Medina. Frishkopf argues that this Saudi style of Qur'anic recitation sonically promotes reformist-revivalist Islamic ideology. It expresses a direct relationship to God, one that is affectively colored by fear, awe, and repentance. This ideology opposes the traditional Sufiinfluenced mystical-aesthetic values of Egyptian Islamic practice (Frishkopf 2009: 100).

What happens when these Middle Eastern recitation styles come to Xinjiang? Do the ideological attachments they signal in Egypt remain true for Uyghur listeners? Can this semiotic system proposed by Frishkopf be applied to the ways in which Qur'anic recitation is listened to, interpreted and reproduced in Uyghur society?

\section{Abdul Basit comes to Aqsu}

In Uyghur society, contexts of recitation include Friday prayers and daily recitation of the complete Qur'an over the course of the thirty days of Ramadan in the larger Friday mosques. It is also practised during funerals and other life-cycle rituals in the home. Ramadan may also be marked by 
practice of inviting the mosque community (jäma'ät) to an evening meal (iptar) followed by a khätmä - a complete simultaneous recitation by thirty reciters of the thirty juz of the Qur'an. Similar rituals of hospitality and recitation are performed for mäwlud - celebrations of the birth of the Prophet Muhammad. Another form of recitation in the home is performed by women ritual specialists (büwi) for the purpose of healing or expulsion, women's funerals, or to mark the night of Barat (the $14^{\text {th }}$ night of the Islamic month of Shabān). Sufi groups also recite from the Qur'an as part of their sama rituals in officially recognized lodges (khaniqa) or in members' homes. Qur'anic recitation is taught in the Islamic Institute, and since the 1990s, the Islamic Association has organized Qur'anic competitions at regional and national level. As we have seen, recordings of recitation in the form of cassettes, VCDs, mobile phone apps, and other gadgets have been sold in Uyghur bazaars both openly and covertly since the mid-1980s, and pilgrims returning from the hajj commonly give cassettes of Qur'anic recitation as gifts.

During fieldwork in 2012, I discussed recitation style with the Damolla, an officially appointed cleric of the chief mosque of a county town in southern Xinjiang. In the 1980s, China's Islamic Association began to establish relations with Islamic centres of learning in the Middle East. Up to this time, according to the Damolla, the style or 'voice' (awaz) of Uyghur recitation was local, but from the 1980s foreign styles, the 'Arab voice' started to be introduced:

In our county, my father's teacher (ustaz) was the first to introduce the Arab qira'ät [recitation style] from Saudi Arabia. He studied for seven years in Mecca. Now the local style has gone. Everyone uses the Arab style ... Why? It's fine to lose our own style, the Arab style is good. The whole Muslim world is using it. We didn't adopt it before because links were weaker, we didn't have so many opportunities to travel.

Yet Saudi Arabia is clearly not the only source for Uyghur reciters to access 'Arab styles'. Damolla also waxed lyrical about the recitation of Abdul Basit, one of the leading $20^{\text {th }}$ century exponents of the Egyptian classical style:

We are all following Abdul Basit; Muslims in China, and across the whole Islamic world. It's fashionable to copy his qira'ät, his tajwid, his awaz [vocal style]. No-one has yet been born to take his place. .. When he reads a verse (ayat), every word is in its proper place. His voice and breath last a long time. I don't know any better than him. ... I am also trying to follow his style at the moment. When I recite in his style and my voice sounds like him people value it more; it strengthens my reputation.

It is clear from this discussion that Middle Eastern styles are entering Uyghur society, and that they are highly valued, even to the extent that they are supplanting local styles. Trained reciters like Damolla also possess detailed knowledge of specific styles and individual reciters. In order to better understand the meanings carried by new styles of Qur'anic recitation as they are absorbed into Uyghur society, we need to listen in detail to how these sounds are reproduced, sounded and embodied in specific contexts of Uyghur religious life. In the next section, I discuss a form of women's ritual practice which was central to religious life in the village where I conducted the bulk of my fieldwork, focusing on the ways in which new styles of Qur'anic recitation are entering this practice, and the ways in which practitioners interpret them.

\section{Qur'anic recitation in women's home-based rituals}

Uyghur women are marginalized by official Islam in Xinjiang - excluded from mosques and from study at the Islamic Institutes - but they may play a central role in home-based religious practices through participation in the extraordinary noisy rituals called khätmä which are led by ritual specialists called büwi. Büwi women prepare the bodies of deceased women for burial, and lead 
gatherings of women for vigils (tünäk) following a death. They are invited to people's homes to recite and pray in order to dispel misfortune or heal illness, and they perform large-scale rituals at key points in the Islamic calendar. The role of büwi is often thought to be attached to the wives of male religious clerics, but the four women I worked with during fieldwork were married to peasant farmers or small traders, and had either inherited the role from their mother or had found their own path towards the role of ritual specialist. Their rituals involve Qur'anic recitation, singing religious hikmät lyrics, rhythmic repetitive dhikr chanting, and a circling form of sama dancing (Harris 2014). Notions of faith, sin and redemption, and emotional expression - specifically weeping - are central to the efficacy of their ritual practice and to the büwi's high status within village society. As the senior büwi in our fieldwork area explained:

[Büwi are] women who really believe in Allah, that Allah created us. If people doubt their faith, and wonder if is it true or false then they will not cry and the sin will not be relieved.

I attended and recorded two of these rituals, in 2009 and in 2012, during which the same büwi - a young woman whom I'll call Aygul who was regarded as a powerful ritual practitioner - recited from the Qur'an in styles which were evidently linked to the sound world of the Middle East.

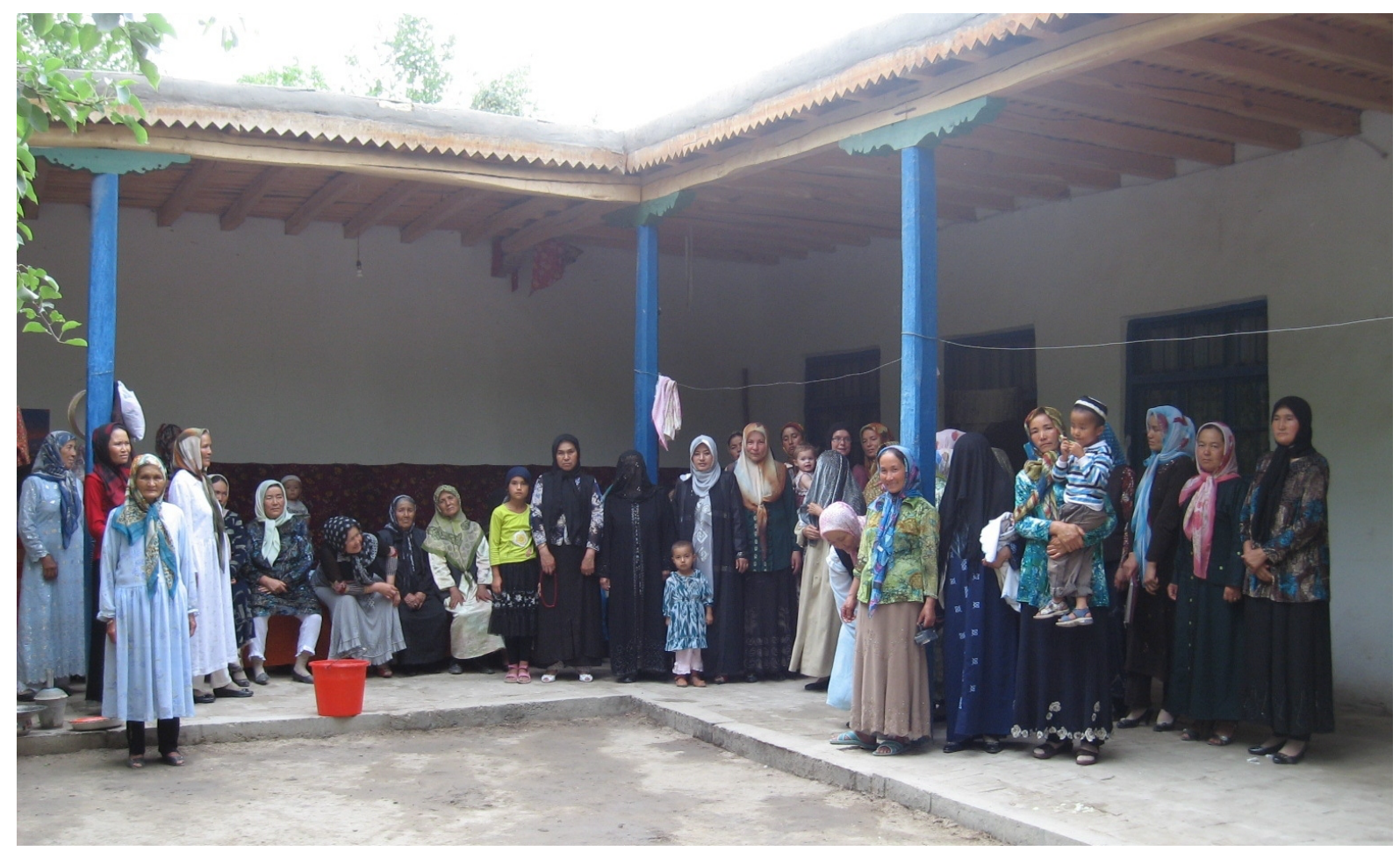

Figure 3: Women gather in front of a village house after a khätmä. Courtesy of Aziz Isa

The 2009 ritual which I attended is normally performed on the night of Barat when, according to traditional Uyghur belief, the good and bad deeds of the dead are weighed in the balance (BellérHann 2008: 355-360). It is a ritual of intercession, pleading for the alleviation of sin, performed on behalf of the whole community, and the recited verses from the Qur'an and prayers dwell on themes of death, judgement, and forgiveness. This is one of the ritual 'good deeds' (sawab) characteristic of rural Uyghur Islam, through which the living are connected with the dead on a family and communal level, and which serve to underpin the deep-seated reciprocal ties of village society. The women recited a series of repetitive prayers, dhikr, led by senior büwi of the locality, gradually increasing in intensity over the course of an hour until many of them were weeping and some fell into trance. Finally Aygul began to recite Surah Al Rahman (Q55). Her recitation was 
beautifully voiced and, unusually amongst the büwi, faithful to correct Qur'anic Arabic pronunciation. She was also recognisably following the 'classical' 20th century Egyptian style, and her phrases were answered by the assembled women with sobs and gasps.

When I returned in 2012, I sat with Aygul to listen back to the recording of this ritual, and we discussed recitation style. She told me:

I learned tajwid from a damolla (religious cleric), a young guy, in Kashgar ... If you don't pronounce the words properly the meaning is lost ... I learned the melody (ahang) from recordings (dai). I bought them from the bazaar in Ürümchi. I just listened to them a couple of times. I like imitating people, so I picked it up easily. I am illiterate, and I never went to school, but I studied the Qur'an for twelve years, so I can copy a voice when I hear it ... I learned this one from a recording of Sadiq Ali [a prominent, Egyptian-trained, Pakistani reciter]. He's a top student of Abdul Basit.

We also talked about the Saudi style of recitation. I played her a recording of the well-known Saudi preacher and reciter, Abdurahman Sudais. 'Ah yes', she said. 'I've learned him too. I'll recite some for you at our next ritual.'

This ritual, led by Aygul herself in August 2012, was performed to help a village woman who was recovering from a major operation. A bowl of water was placed in the centre of the circle, and after the conclusion of each set of dhikr the women blew into it with a noisy 'fshew', transferring the blessings earned by their recitation into the water, which would later be drunk by the patient. The ritual followed the normal pattern of rising emotional intensity, weeping and trancing. At its conclusion, Aygul recited Surah Al-Fatiha (Q1), in a slow, portentous manner, clearly imitating the Saudi style of recitation.

Aygul inserts into her ritual practice both the Egyptian and the Saudi styles of recitation. If we follow Frishkopf's semiotic model we might think it highly appropriate that the Egyptian style - with its links to mystic, Sufi-influenced modes of Islam - should be brought into the context of this ritual which also draws upon Sufi practices of dhikr and sama dance. The inclusion of the Saudi style, on the other hand, may strike us as bizarre. Here is a style linked to strongly, even violently, anti-Sufi ideology. This is a form of Islam that preaches, above all, a direct relationship with God, and as such is strongly opposed to the kind of ritual intercession which these büwi are engaged in.

The ritual practices of the büwi, along with other 'traditional' or 'local' practices, have been much criticized by Uyghur reformists over the past two decades. Reformists have argued that there is no Qur'anic basis for rituals such as these; they regard them as 'un-Islamic' innovations (bidät), local traditions and 'superstition' (khurapatliq) from which Islam should be 'purified' (Schrode 1999). Why would Aygul draw upon this style if it retained its semiotic associations with this form of Islam? Surely this is a case of radical semantic and affective drift; the kind of disjuncture of sounds and meanings that is often remarked upon in studies of the global circulation of music (ErImann 1999: 187). It appears that as the disembodied sounds of Qur'anic recitation circulate around the globe with increasing ease and rapidity, their semiotic meanings are similarly detached and their sounds are re-signified.

Many observers of the Islamic world have pitted a supposedly tolerant and hybrid local Islam against the purifying practices of modernist or reformist individuals and groups (Soares and Osella 2009: 8). But it is difficult to make a clear-cut distinction between 'orthodox' Islam and Sufi-influenced Islam in Xinjiang. Sufi rituals provide one dimension of a broad spectrum of religious beliefs that individuals may draw upon. Senior religious leaders in mosques and madrassahs throughout Xinjiang have been known to undertake leading roles within Sufi orders (täriqät), and the Sufi orders have 
historically been closely tied to political power. This blurring of boundaries and factions continues today.

The ritual practices of rural Uyghur women are highly adaptable and responsive to social change, as their practitioners - even within their remote villages - confront and engage with the complexities of contemporary globalized society. Although their practice has clearly absorbed elements of Sufi ritual, büwi do not necessarily identify themselves as Sufis, indeed most of the women I spoke with had little awareness of the Sufi orders that are active in Xinjiang today. Likewise, absorbing the sounds of Wahhabism does not necessarily denote a reformist attitude. For Aygul, as for other reciters, rather than indexing rival ideologies, what both the Egyptian and Saudi styles index is modernity. 'Our level is very low', says the Damolla of Uyghur Qur'anic recitation, echoing the prevalent state discourse of development. In China's Muslim communities, this thirst for modernity has been linked to a sense of exclusion or marginalization from the modernizing agenda of the state. In her study of Hui Muslim Chinese in mid-1990s Xi'an, Maris Boyd Gillette lays emphasis on the links between modernization and the new forms of Islam penetrating this community - which she terms 'Arabization':

Like modernization, Arabization included a cluster of ideas about development for Muslims. ... although proponents of Arabization used the language of authenticity and the 'original' Islam to legitimate the changes they proposed, Arabization also incorporated elements of modernization as exemplified by the oil-rich countries of the Middle East. Arabization provided residents with an alternative ideological scale on which to evaluate themselves and a scale of development that excluded the CCP government and the Han minzu. (Boyd Gillette 2000: 76)

Aygul, likewise, feels the need to make herself strong and to make herself modern, in part in response to pressure from state religious policies, in part in response to criticism from reformists. ${ }^{11}$ 'Now our rituals are even stronger than before', she said, 'There are restrictions on gatherings, so it is harder to meet, but we understand better than before. Our heads are like computers; more developed.' Cyborg-like, magpie-like, Aygul mimetically absorbs and deploys these 'foreign styles' of recitation within the context of a very local form of ritual.

\section{Conclusions}

The case studies in this article reveal some of the complexity of the interactions between local systems of meaning and experience and global forms of religious transformation. By listening in on the new religious modalities that are circulating in Uyghur society, and by paying attention to how people listen to them, we can begin to perceive how they help to construct new ways of being Muslim and being Uyghur in Xinjiang. Contemporary debates on ways of being Muslim across contemporary Xinjiang are complex, messy and confused. This is in part due to the severe restrictions on religious education and religious media imposed by the state, which make much of this knowledge an illicit pursuit, and thus impede the development of a clearer understanding of the different ideological strands. Likewise, the Xinjiang authorities do not appear to differentiate between different ideological forms of Islam. At the time of writing, many kinds of religious gatherings, including those of the büwi, are outlawed, and the büwi themselves are regularly harassed by the local police, accused of conducting illegal religious activities which, as we have seen, are regularly conflated with extremism and terrorism in state media reports (Harris 2013).

The use of religious media in Xinjiang exemplifies the processes of decontextualization and abstraction typical of digitally mediated productions. What is beyond doubt is the thirst for these new ways of being Muslim. The religious utterances of rural Uyghur women are performed in active dialogue with global flows of Islamic ideologies, and also with current social and ideological change 
within Xinjiang. State media depicts Islamic media imported from outside in Xinjiang as purveyors of religious extremism and promoting terrorism. The new religious media is undoubtedly weakening the position of the traditional interpreters of Islam, notably the authority of Xinjiang's official imams, but what state media refers to as extremist or jihadi propaganda, often subsumes a far wider set of religious dispositions that the state regards as potentially threatening to stability.

Equally, when Uyghurs encounter new forms of sounded practice and reproduce them as part of their own practices, they resignify them. Thus, for rural Uyghur women, the Egyptian and Saudi recitation styles are not symbols of opposing religious ideologies; they are new tools that they can draw on to strengthen their own religious practice. They are symbols of an alternative modernity, but they reflect and enact locally produced channels of spiritual and political power. In fact, my research shows that a very wide range of different ideological and affective relationships with Islam is promoted through the available media, and most Uyghurs who consume them are not using them in order to pursue specific ideologies. It would seem more appropriate to argue that what they seek are particular affective religious experiences.

Of particular note are the ways in which many of these religious media items use visceral sounds and imagery to communicate eschatological themes of suffering, death and judgement. These productions are threatening to the state on two levels: they defy the rational and secular project of the state, and simply through their promotion of the fundamental religious disposition of being 'God-fearing' they dilute the authority of the state by promoting an alternative, more powerful sanction. These forms of Islamic media, sometimes drawing on the sound world of horror films, promote a visceral fear of God, like the snake-monkey-woman discussed above who provides a lesson for women in the monstrousness of impious behaviour. The state reacts with horror at the spread of what it perceives as alien, anti-modern, and hence threatening ways of being. It invokes the trope of Islamic terror, which then enables new violence to be unleashed against the supposed terrorists. Thus, it may be appropriate to view the current cycle of violence in Xinjiang, not in terms of an ideological clash between radical Islam and the Communist state, but as a dialectical relationship between two opposing conceptions of horror and modernity: each one the product of radically different cultures of listening.

\section{References}

Becquelin, Nicolas (2004), 'Criminalizing Ethnicity: Political Repression in Xinjiang', China Rights Forum, 39-46.

Bellér-Hann, Ildikó (2008), Community Matters in Xinjiang 1880-1949: Towards a Historical Anthropology of the Uyghur, Leiden and Boston: Brill.

Boyd Gillette, Maris (2000), Between Mecca and Beijing: modernization and consumption among urban Chinese Muslims, Stanford: Stanford University Press.

Eickelman, Dale F. and James Piscatori (2004), Muslim Politics, New Jersey: Princeton University Press.

Eisenberg, Andrew J. (2009), The Resonance of Place: Vocalizing Swahili Ethnicity in Mombasa, Kenya, Ph.D. Dissertation, Columbia University. 
Erlmann, Veit (1999), Music, Modernity and the Global Imagination: South Africa and the West, New York and Oxford: Oxford University Press.

(ed.) (2004), Hearing Cultures: Essays on Sound, Listening and Modernity, Oxford: Berg.

Feld, Steven (1996), 'Waterfalls of Songs: An Acoustemology of Place Resounding in Bosavi, Papua New Guinea', in Steven Feld and Keith H. Basso (eds.), Senses of Place, Santa Fe: School of American Research Press, pp. 91-135.

Frishkopf, Michael (2009), 'Mediated Qur'anic Recitation and the Contestation of Islam in Contemporary Egypt', in Laudan Nooshin (ed.), Music and the Play of Power in the Middle East, North Africa and Central Asia, Farnham: Ashgate, pp. 75-114.

Fuller, Graham E. and Jonathan N. Lipman (2004), 'Islam in Xinjiang', in S. Frederick Starr (ed.), Xinjiang: China's Muslim Borderland, Armonk, NY: M. E. Sharpe, pp. 320-52.

Gladney, Dru (2004), Dislocating China: Muslims, Minorities, and Other Subaltern Subjects, Chicago: University of Chicago.

Harris, Rachel (2002), 'Cassettes, Bazaars and Saving the Nation: the Uyghur Music Industry in Xinjiang, China', in Timothy Craig and Richard King (eds.), Global Goes Local: Popular Culture in Asia, Vancouver: University of British Columbia Press, pp. 265-83.

(2013), 'Harmonizing Islam in Xinjiang: sound and meaning in rural Uyghur religious practice', In Bellér-Hann, Ildiko and Brox, Trine, (eds.), On the Fringes of the Harmonious Society: Tibetans and Uyghurs in Socialist China. Copenhagen: NIAS Press, pp. 293-317.

Hann, Chris (ed.) (2006), The Postsocialist Religious Question: Faith and Power in Central Asia and East-Central Europe, Berlin: LIT Verlag.

Harris, Rachel (2014), 'The Oil is Sizzling in the Pot: Sound and Emotion in Uyghur Qur'anic Recitation', Ethnomusicology Forum, 23: 3, pp. 331-359.

Henig, David (2012), "This is our little hajj': Muslim holy sites and re-appropriation of the sacred landscape in contemporary Bosnia', American Ethnologist, 39: 4, pp. 752-766.

Hillman, Ben (2004), 'The Rise of the Community in Rural China: Village Politics, Cultural Identity and Religious Revival in a Hui Hamlet', The China Journal, 51, pp. 53-73.

Hirschkind, Charles (2006), The Ethical Soundscape: Cassette Sermons and Islamic Counterpublics, New York: Columbia University Press.

(2012), 'Experiments in Devotion Online: the YouTube khuțba', International Journal of Middle East Studies, 44, pp. 5-21.

Ho Wai-Yip, (2010), 'Islam, China and the Internet: Negotiating Residual Cyberspace between Hegemonic Patriotism and Connectivity to the Ummah', Journal of Muslim Minority Affairs, 30: 1, pp. 63-79.

Kandiyoti, Deniz, and Nadira Azimova (2004), 'The Communal and the Sacred: Women's Worlds of Ritual in Uzbekistan'. Journal of the Royal Anthropological Institute 10: 2, pp327-350.

Mahmood, Saba (2005), Politics of Piety: the Islamic revival and the feminist subject, Princeton \& Oxford: Princeton University Press. 
Marsden, Magnus (2005), Living Islam: Muslim Religious Experience in Pakistan's North-West Frontier, Cambridge: Cambridge University Press.

(2007), 'All-male sonic gatherings, Islamic reform, and masculinity in northern Pakistan', American Ethnologist, 34: 3, pp. 473-490.

Millward, James A. James A. Millward. Violent Separatism in Xinjiang: A Critical Assessment. (Washington, DC: East West Center, 2004).

(2009), 'Introduction: Does the 2009 Ürümchi violence mark a turning point?', Central Asian Survey, 28: 4, pp. 353-56.

Nelson, Kristina (2001), The Art of Reciting the Qur'an, Cairo: American University in Cairo Press.

Panagia, Davide (2009), The Political Life of Sensation, Durham \& London: Duke University Press.

Rasmussen, Anne K. (2010), Women's Voices, the Recited Qur'an, and Islamic Musical Arts in Indonesia, Berkeley: University of California Press.

Samuels, David W., Louise Meintjes, Ana Maria Ochoa, and Thomas Porcello (2010), 'Soundscapes: Toward a Sounded Anthropology', Annual Review of Anthropology, 39.

Schrode, Paula (2008), 'The Dynamics of Orthodoxy and Heterodoxy in Uyghur Religious Practice,' Die Welt des Islams, 48, pp. 394-433.

Smith Finley, Joanne (2013), The Art of Symbolic Resistance: Uyghur Identities and Uyghur-Han Relations in Contemporary Xinjiang, Leiden: Brill.

Soares, Benjamin and Filippo Osella, (2009), 'Islam, Politics, Anthropology', Journal of the Royal Anthropological Institute, Vol. 15, Issue Supplement s1, pp. S1-S23.

Tambiah, Stanley (1996), Leveling Crowds: Ethnonationalist conflicts and collective violence in South Asia. Berkeley \& Los Angeles: University of California Press.

Uyghur Human Rights Project (2013), China's Iron-Fisted Repression of Uyghur Religious Freedom, Washington DC: UHRP.

Waite, Edmund (forthcoming), Muslims on the Edge of China: Religious Knowledge and Authority Amongst the Uyghurs of Xinjiang, Abingdon: Routledge.

\footnotetext{
${ }^{1}$ I spent the summers of 2006, 2009, and 2012 based in a village in the southern region of Aqsu, accompanied by my husband, Aziz Isa, to whom I am - as ever - indebted for his invaluable assistance with interviews, translation and research.

2 Waite notes that Sayyid Qutb's 'Signposts Along the Road', which is regarded as a global manifesto of contemporary radical Islam, and various works by the Hizb ut-Tahir theorist Taqiuddin Nabhani have been translated into Uyghur and informally circulated within Xinjiang (Waite forthcoming: chapter 2).

${ }^{3}$ The way of life prescribed as normative for Muslims on the basis of the teachings and practices of Muhammad and interpretations of the Qur'an.

${ }^{4}$ A conservative branch of Sunni Islam which preaches a return to the fundamentals of Islam. Wahhabism was a popular revivalist movement instigated by an eighteenth century theologian, Muhammad ibn Abd alWahhab (1703-1792) from Najd, Saudi Arabia who criticized the moral decline and political weakness in the Arabian Peninsula and condemned popular cult of saints and shrine visitation. It has become the dominant
} 
form of Islam in Saudi Arabia, and is widely promoted around the world, supported by the political and financial power of the Saudi government.

${ }^{5}$ In Uyghur Islam, näzir are held on the 3rd, 7th and 40th day and one year after death. If the family is rich then the whole community of the Friday mosque (jäma'ät) are invited for food and recitation of the Qur'an which builds up religious merit on behalf of the deceased. Families often go to considerable expense to mark the status of deceased and of family.

${ }^{6}$ http://www.themorningstarr.co.uk/2010/02/13/snake-with-a-human-head-found-inmalaysia/\#axzz2TpIOJFIk (accessed 20 May 2013).

${ }^{7}$ Uyghurlarni aldawatqan sakhta möjuzlär (The fake miracles confronting the Uyghurs), Jawhar1 bbs.alkuyi.com (accessed 28 June 2012).

${ }^{8}$ The Xinjiang authorities have repeatedly sought to blame incidents of violence and disorder on this predominantly secular, human rights campaigning organisation; see (Millward 2004 and 2009).

${ }^{9}$ http://www.euronews.com/newswires/2151506-china-police-target-online-jihad-talk-amid-rumourcrackdown/ (accessed 5 January 2014).

${ }^{10}$ http://www.nytimes.com/2009/09/04/world/asia/04china.html?_r=0 (accessed 29 Nov 2014).

${ }^{11}$ Ben Hillman (2004) similarly describes how a small Hui community in Yunnan learned lifestyles from other Muslims in China and abroad and gained the empowering opportunity to reject 'backward minority status'. 